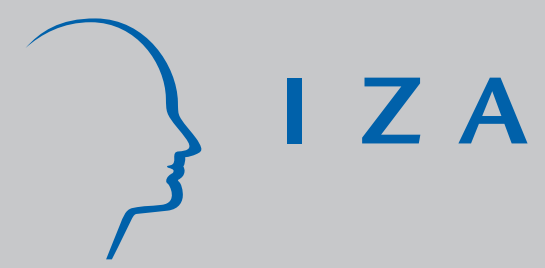

IZA DP No. 7237

A Structural Model of Educational Attainment in Canada

Jorgen Hansen

Xingfei Liu

February 2013

Forschungsinstitut zur Zukunft der Arbeit Institute for the Study of Labor 


\title{
A Structural Model of Educational Attainment in Canada
}

\author{
Jorgen Hansen \\ Concordia University, \\ CIRANO, CIREQ and IZA \\ Xingfei Liu \\ Concordia University
}
Discussion Paper No. 7237
February 2013

\author{
IZA \\ P.O. Box 7240 \\ 53072 Bonn \\ Germany \\ Phone: +49-228-3894-0 \\ Fax: +49-228-3894-180 \\ E-mail: iza@iza.org
}

Any opinions expressed here are those of the author(s) and not those of IZA. Research published in this series may include views on policy, but the institute itself takes no institutional policy positions. The IZA research network is committed to the IZA Guiding Principles of Research Integrity.

The Institute for the Study of Labor (IZA) in Bonn is a local and virtual international research center and a place of communication between science, politics and business. IZA is an independent nonprofit organization supported by Deutsche Post Foundation. The center is associated with the University of Bonn and offers a stimulating research environment through its international network, workshops and conferences, data service, project support, research visits and doctoral program. IZA engages in (i) original and internationally competitive research in all fields of labor economics, (ii) development of policy concepts, and (iii) dissemination of research results and concepts to the interested public.

IZA Discussion Papers often represent preliminary work and are circulated to encourage discussion. Citation of such a paper should account for its provisional character. A revised version may be available directly from the author. 
IZA Discussion Paper No. 7237

February 2013

\section{ABSTRACT}

\section{A Structural Model of Educational Attainment in Canada ${ }^{*}$}

In this paper, we develop and estimate a structural, dynamic model of schooling decisions using data extracted from the Canadian Youth in Transition Survey (YITS). The model incorporates forward-looking behavior and expectations about future benefits from investing in education. The results suggest that the effect of an increase in parental income on educational attainment is modest. For example, a 25 percent increase in parental income is predicted to increase post-secondary education (PSE) attendance by one percent only. However, our results indicate that financial resources, other than parental income, play a role in PSE enrollment. In particular, our model predicts that an increase in PSE tuition fees by $\$ 2,500$ per grade level (for grade 13 and above) will reduce attendance in these grades by almost 9 percentage points for males and by 6.5 percentage points for females. We also simulate the impacts of changes in Programme for International Student Assessment (PISA) reading scores. Specifically, an increase of test scores with one standard deviation (which is comparable to the difference in average score for high school drop-outs and those with some PSE) increases PSE attendance by 10.2 percentage points for males and by 6.6 percentage points for females. At the same time, high school dropout rates are predicted to fall by 3.2 percentage points for males and by 2.8 percentage points for females. We also take advantage of the dynamics of the model and explore how a 25 percent increase in future wages for PSE students will affect current schooling decisions. This leads to an increase in PSE attendance by 2.2 percentage points for males and by 3.1 percentage points for females.

JEL Classification: J01, I21

Keywords: educational attainment, structural estimation, forward-looking behavior, parental income, tuition fees, cognitive ability

Corresponding author:

Jorgen Hansen

Concordia University

Department of Economics

1455, de Maisonneuve Blvd. W.

Montreal, Quebec, H3G 1M8

Canada

E-mail: Jorgen.Hansen@concordia.ca

*Comments from two anonymous reviewers are gratefully acknowledged. 


\section{Introduction}

Educational attainment is a fundamental determinant of a wide range of individual and societal outcomes. Several economic and labor market outcomes such as wages, occupation and unemployment - critically depend on educational attainment. Further, many social outcomes, such as crime, health and social status, also depend significantly on educational attainment. Given this, policies shaping educational attainment are both important and of broad interest at both individual and societal levels.

It is therefore not surprising that the literature on the determinants of educational attainment is voluminous. Concerns over accessibility to higher education have led many researchers to focus on the role of family income and financial constraints on educational attainment. ${ }^{1} \mathrm{~A}$ majority of these studies examine educational attainment in the U.S. and only a few have examined Canadian data (see for example Belley et al (2011), Frenette (2007) and Coelli (2005)).

In this paper, we provide additional evidence on the role of family background variables, including family income, in shaping schooling attainment in Canada. To do so, we develop and estimate a structural, dynamic model of schooling decisions using data extracted from the Canadian Youth in Transition Survey (YITS). Economists and other social scientists agree that a major determinant of educational investments, apart from cognitive skills and family background, is expected future rewards. A model of educational attainment must therefore incorporate forward-looking behavior and expectations about future benefits of the investment. The model we develop contains this feature and it enables us to evaluate the impact of changes in expected wage returns on educational decisions. The estimated model also allows us to evaluate different counterfactual policy alternatives that change the direct costs of attending higher education.

The importance of evaluating alternative designs of educational policies cannot be underestimated and there exist a large research literature on this topic.

\footnotetext{
${ }^{1}$ See for example Deming and Dynarski (2009), Kane (2006), Cameron and Taber (2004), Dynarski (2003), Carneiro and Heckman (2002), Keane and Wolpin (2001) and Cameron and Heckman (1998, 2001).
} 
Most evaluations of educational policies rely on quasi-experimental approaches to econometrics, including instrumental variable and difference-in-difference techniques. Proponents of these approaches emphasize the identification of causal effects of observed policy interventions using minimal assumptions. However, as discussed in Keane (2010, page 48) “... all statistical inference relies on some untestable assumptions". Moreover, they are often of limited use for policy makers since it is not possible to extrapolate the results from one experiment/policy to another setting. Thus, to evaluate two different policy alternatives (or for that matter, the same policy experiment but in different geographical regions), we would need data from two independent ("natural") experiments.

An alternative to the quasi-experimental approach is to formulate a structural or behavioral model and estimate the parameters of the educational production function. Given estimated structural parameters, the researcher can analyze how educational attainment is affected by changes in parental education, family income, and cognitive achievement. Moreover, it is possible to compare expected outcomes under alternative policies with these estimates. This is the approach that we adopt in this paper.

Like quasi-experimental approaches, structural models also rely on a number of assumptions. However, they are generally explicitly described and this enables an assessment of the credibility of the model and the results. In practice, the researcher does not know the correct statistical and/or behavioral assumptions required to estimate a model. It is therefore neither possible, nor sensible, to claim which approach to estimation is more flexible, unless one knows the full data generating process.

The structural model that we use in this paper is based on the ones used in Belzil and Hansen (2002 and 2007), Hansen, Liu and Kucera (2011a and 2011b) and Liu (2011). In particular, we assume that students decide sequentially whether to enter the labor market or to continue to accumulate schooling. ${ }^{2}$ Further, students are assumed to be rational and forward-looking individuals who maximize the

\footnotetext{
${ }^{2}$ Although the model is sequential, it allows for school interruptions.
} 
discounted expected lifetime utility over a finite horizon. Educational decisions are modeled from age 16 and onwards recognizing the possible endogeneity of the highest grade completed at age 16. ${ }^{3}$ The dynamic programming model is solved using backward recursions and the parameters of the model are estimated using maximum likelihood techniques.

The behavioral parameters are estimated using data from the reading cohort of the Youth in Transition Survey (YITS - cohort A). YITS record detailed family environment and education advancement information on respondents who were 15 years old in 1999 and provide an excellent opportunity to study how family environment together with cognitive skills shape young adults' educational decisions. Further, the richness of the data combined with a general economic model allows us to disentangle the effects of family background factors and ability measures on educational attainment. ${ }^{4}$

Before analyzing the effects of changes in observed characteristics and performing policy simulations, we validate the model by comparing predictions generated by the model with the observed schooling distributions, both for males and females. In both cases, the two distributions are very similar.

The results suggest that the effect of an increase in parental income on educational attainment is very modest, even though the estimated parameters associated with parental income are statistically significant. In particular, increasing parental income with 25 percent is predicted to increase post-secondary education (PSE) attendance by less than one percent. Similarly, high school dropout rates are only marginally affected by this income change.

To further analyze the role of parental income, we explored how a fixed monetary transfer would change the distribution of educational outcomes by adding approximately $\$ 5,000$ to observed parental income. ${ }^{5}$ Again, the effect on PSE

\footnotetext{
${ }^{3}$ Students may have completed different grade levels by age 16 and this, in turn, may be related to family background, cognitive skills as well as unobserved factors. If this is the case, the highest grade completed at age 16 is endogenous.

4 We use PISA reading scores as (scholastic) ability measures.

5 We increased parental income with one standard deviation $(\$ 5,130$ for males and $\$ 5,330$ for females). Note that this increase can be thought of as an increase of parental income at each grade level.
} 
attendance is small; it increases with 2.1 percent for males and 3.2 percent for females. These results suggest that, although there is a relatively strong correlation between parental income and educational attainment, only a small portion of the observed variation in education is explained by differences in parental income.

While changes in parental income have limited impacts on educational outcomes, the effects of changes in PISA reading scores are much larger. As an illustration, an increase of the reading score with one standard deviation reduces the high school dropout rates with around 40 percent for both males and females. ${ }^{6}$ Moreover, PSE attendance is predicted to increase with 14 and 8 percent, respectively for males and females. We also considered the effects from increasing reading scores for everyone who had a score lower than 500 to 500 . This is a more modest ambition that would impact fewer students, especially for female students (where the mean score for female high school dropouts is 496). The results from this simulation suggest that the high school dropout rate will decline with 31 percent for males and 23 percent for females and PSE attendance will increase with 21 percent for males and 8 percent for females.

Overall, the responses from changes in PISA reading scores are substantially larger than those observed when we counterfactually increase parental income. These results clearly illustrate that scholastic ability play a more important role in determining educational success than parental income, a finding that is consistent with U.S. evidence (e.g. Cameron and Heckman (1998 and 2001) and Carneiro and Heckman (2002)).

We also used the model to simulate the impact of a $\$ 2,500$ increase in tuition fees for PSE. The results suggest that PSE attendance will drop by 12 and 8 percent, respectively for males and females, as a result of this fee increase. While these reactions exceed those for parental income changes, they are relatively modest considering the magnitude of the fee increase (which corresponds to around 50 percent of the current Canadian average).

\footnotetext{
${ }^{6}$ The magnitude of one standard deviation in PISA reading scores is comparable to the difference in average scores for high school dropouts and those with some PSE.
} 
Our model can also be used to assess the Quebec government's decision to increase university tuition fees with $\$ 1,625$ and we find that university attendance will decrease by a modest 3.2 percent for male students and by 2.1 percent for females. ${ }^{7}$ Further, the reductions are not significantly related to observable characteristics, such as parental education and income. Thus, we find no support for the concerns that have been raised by some student associations that the increase will disproportionately affect students from poor families.

As mentioned above, a key feature of our model is that students are forwardlooking and consider the effect of education on future wage outcomes when making schooling decisions. This is generally not the case in previous studies and it enables us to explore how changes in the return to higher education will affect educational attainment. In a counter-factual experiment we raised the return to education with 25 percent. This increased PSE attendance by 3 percent for males and 4 percent for females.

Our findings also show that less than three percent of the variation in predicted schooling can be explained by variation in parental income. On the other hand, parental education and scholastic achievement explain about 18 percent of the variation. This reinforces our conclusion that scholastic achievement is a major factor determining schooling attainment and that parental income has a relatively small impact

This paper proceeds as follows. The next section briefly reviews the related literature on educational attainment. We describe the economic and econometric models in Section 3. In Section 4 we present the main features of the YITS data. Section 5 contains an assessment of how the model predictions compare with observed outcomes. In this section, we also illustrate the impact of changes in parental education, parental income, PISA reading scores and wage returns on educational attainment. Section 6 concludes.

\footnotetext{
7 The original proposal was to introduce the fee increase gradually by $\$ 325$ per year over five years. In our simulations, we have assumed an instantaneous increase instead. Therefore, assuming that our model is correctly specified, our predicted reductions in university enrolments can be viewed as upper bounds.
} 


\section{Related Literature}

Educational attainment is one of the most important determinants for individual (and societal) prosperity and it is therefore not surprising that it has been extensively researched. It has attracted attention from many different disciplines in social sciences, including economics and sociology. The following review will focus on the academic literature in economics although important work in other disciplines will be considered.

Haveman and Wolfe (1995) provide an extensive survey of both the economic and sociological literature on educational attainment. ${ }^{8}$ Most of the studies they review use longitudinal data and apply either linear or nonlinear regression methods (e.g. OLS, Probit, Logit) to analyze the relationship between observable characteristics and educational attainment. The level of human capital of parents is documented to be an important determinant of schooling attainment. This factor, regardless of how it is defined, consistently has a statistically significant effect and it is also quantitatively important. Other important determinants, according to their survey, are family economic resources, family structure (e.g. living in a one- vs. twoparent family) and number of siblings.

Some of the recent work in economics has focused on decisions to drop out of high school (see for instance Parent, 2006; Bowlby and McMullen, 2005; Rumberger and Lamb, 2003; Tyler et al., 2000 and Eckstein and Wolpin, 1999) or the decision to invest in higher education (see Belley et al, 2011; Frenette, 2007; Coelli, 2005; Drolet, 2005; Finnie et al., 2005; Frenette, 2005; Corak et al., 2005; Rivard and Raymond, 2004; Frenette, 2003; and Christofides et al., 2001 for examples of Canadian studies). A few of these studies use structural economic models (Eckstein and Wolpin, 1999) while other document the relationship between educational attainment and observed family and individual characteristics using regression methods.

\footnotetext{
${ }^{8}$ In addition to reviewing past work on determinants of schooling, Haveman and Wolfe (1995) also review research on economic mobility, fertility and earnings.
} 
There also exist a large number of papers that have studied schooling attainment more broadly. Generally, this branch of the literature has recognized the sequential nature of educational decisions and Mare (1980) was one of the first to estimate a transition model where educational attainment is the outcome of a sequence of grade transition probabilities. He also estimated the effect of family background characteristics on the transition probabilities. A main result in his paper is that the effect of parental characteristics decline with grade levels. For example, the effect of parental income on grade transitions decline by more than 50 percent between elementary school and college. Similar reductions are found for the effects of parental education. While family income as well as parental education has large and statistically significant effects on the probability of completing elementary school, the effects of these variables on the probability of completing college are much smaller.

While the grade-transition model recognizes the sequential nature of acquiring education, it assumes that students do not interrupt their schooling attainment. Further, as pointed out by Cameron and Heckman (1998), the model estimated by Mare (1980) ignores any omitted characteristics of the family or the individual that influence schooling decisions but are unmeasured by researchers. The omission of such variables may lead to biased estimates of the effects of observed characteristics on schooling attainment and may also explain the pattern of declining effects of parental characteristics on grade progression.

Cameron and Heckman (1998) propose an alternative model that controls for unobserved characteristics and their results on the effects of family income and parental education show a pattern that is opposite that of Mare (1980). In particular, they find that the effect of family income is negative for those with less than elementary schooling, is largest for those who graduated from high school but attended no further education, and then decline for grade levels above high school completion.

Recent papers employing the ordered discrete choice model advocated by Cameron and Heckman (1998) include Kucera (2008), McIntosh and Munk (2007), Bauer and Riphahn (2007), Lauer (2003), Lucas (2001), and Ermisch and 
Francesconi (2001). Among these papers, Kucera (2008) is the only one using Canadian data and he focuses on differences in educational attainment between those with immigrant parents and those with Canadian-born parents. Kucera's findings suggest that second-generation immigrants do better in terms of schooling attainment than their counterparts from non-immigrant families.

Another study using Canadian data and a general model of educational attainment is Belzil and Hansen (2006). They estimate, in addition to an ordered probit model, a grade transition model and focus on the role of expected future earnings and parental education on educational attainment in Canada. Their findings suggest that educational attainment increase significantly as expected future earnings increase. The effect is grade level dependent and largest for grade levels beyond high school. They also found smaller effects of parental education than what has previously been reported.

Sun (2008) use an empirical model similar to that of Belzil and Hansen (2006) and applies it to data from the Youth in Transition Survey (YITS). Sun incorporates information on PISA reading and math scores in her estimations and her results show a positive effect of these scores on grade progression. Moreover, the effect of parental education, although still statistically significant, decline when she includes PISA scores.

Liu (2011) derives a behavioral model similar to that in Belzil and Hansen (2002) and estimates the parameters using data from both Canada (YITS - cohort A) and the U.S. (National Longitudinal Survey of Youth - 1997 cohort). Like Kucera (2008), Liu is particularly interested in the role of immigration policies on educational attainment of second-generation immigrants in the two countries. The results indicate that family characteristics, in particular parental education and income, have significant positive effects on children's schooling attendance. Moreover, youths in the U.S. appear more responsive to changes in parental income than youths in Canada.

Belley et al (2011) use data from the 1997 Cohort of the National Longitudinal Survey of Youth and Youth in Transition Survey to analyze the role of parental income on post-secondary education (PSE) attendance. They report a much 
stronger relationship between parental income and PSE attendance in the U.S. relative to Canada, even after controlling for family background and adolescent cognitive achievement. However, despite this finding, they argue that the higher family income attendance gap in the U.S. may not be due to higher tuition fees in the U.S. than in Canada. This is so because of more generous financial aid policies to low-income youth in the U.S. than in Canada.

Although the previous literature on educational attainment and the effects of parental characteristics on school outcomes differ widely in terms data and methodology, there are a number of findings that consistently appear in most studies.

First, parental education is an important determinant, both quantitatively and statistically. For example, Belzil and Hansen (2003), using a structural economic model applied to data from the National Longitudinal Survey of Youth (NLSY79), report that household background variables (especially parents' education) account for about two-thirds of the explained cross-sectional variation in schooling attainment while individual ability accounts for one third.

Second, the economic resources available within the family at the time students are in their early teenage years have also been documented to have important effects on student achievement and grade attainment. To what extent this reflect existence of credit constraints or financial barriers is however unclear. Kane (1994) argues that college enrollment is sensitive towards changes in the cost of attending college. On the other hand, Carneiro and Heckman (2002) suggest that, in general, long-run family factors are more important than short-term income constraints (see also Cameron and Heckman, 1998 and 2001). However, they recognize that some individuals may be limited in their college opportunities and face short-term credit constraints. Further, Cameron and Taber (2004) found little evidence in support of the importance of budget constraints in determining college/university attendance in the U.S. Instead, cognitive skills together with other family background indicators such as parents' education and number of siblings are more important factors in determining college attendances than financial constraints. 
The issue of possible credit constraints in higher education has also been analyzed using Canadian data; see for instance Coelli (2005), Drolet (2005), Finnie et al. (2005) and Corak et al. (2005).

Third, whenever measures of scholastic ability have been included among the control variables, they generally have significant impacts on educational attainment. For example, Heckman et al. (2006) show that cognitive and noncognitive ability has positive effects on educational attainment. For Canada, Frenette and Zeman (2007), Thiessen (2007) and Belzil and Hansen (2006) have shown that high school grade-point average is significantly related to the probability of acquiring schooling beyond high school. Overall, not surprisingly, measures of academic performance and ability are strongly connected to educational transitions.

Fourth, most of the results have been obtained from estimation of linear and non-linear regression models. Only a few studies have used structural models to estimate effects of policy variables on educational outcomes and most of these have used U.S. or Mexican data, see for example Keane and Wolpin (1997 and 2001), Eckstein and Wolpin (1999), Belzil and Hansen (2002, 2003 and 2007), Attanasio et al (2005) and Todd and Wolpin (2006). To our knowledge, the only example of estimation of a structural model of educational attainment using Canadian data, aside from this paper, is Liu (2011).

\section{Economic Model and Estimation}

In this section, we present the structural model that we use to analyze educational attainment using data from YITS. The model is similar to the ones initially derived in Belzil and Hansen (2002 and 2007) where only educational outcomes are modeled. ${ }^{9}$ However, we are not using wage data available in the survey to estimate the parameters in the wage function. Instead, we use data from the 2000 Canadian Census. The reason for this is that many of the observed wages in YITS are part-time wages, wages earned during school breaks or early career wages.

\footnotetext{
${ }^{9}$ While post-educational activities are included in their model, they do not model choices after school completion.
} 
These wages are typically not representative of wages over the life-cycle and may underestimate the returns to both education and work experience.

In short, the model implies that individuals decide sequentially (at the beginning of each time period) whether to enter the labor market or to continue to accumulate schooling. Further, individuals are assumed to be rational and forwardlooking and they maximize the discounted expected lifetime utility over a finite horizon. The model has one control variable, $d_{i t}$, that equals one if an individual decides to stay in school and zero otherwise (in which case the individual decides to leave school and enter the labor market). Finally, educational decisions will be modeled from age 16 and onwards. Below we present a detailed description of the model and the estimation issues.

\subsection{Utility of Attending School}

Formally, in any time period $t$ after age 16 , the instantaneous utility of attending school is represented by the following equation: ${ }^{10}$

$$
U_{i t}^{s}=\ln \left(C_{i t}\right)=\beta_{l} X_{l i t}+\alpha_{j}^{c} I\left(S_{i t}=j\right)+\alpha_{0}^{k} S_{i 0}+a s^{k}+\varepsilon_{i t}^{s}
$$

where $i$ denotes individual. $\ln \left(C_{i t}\right)$ can be interpreted as the current monetary returns of attending school and is a function of observed characteristics $X_{\text {lit }}$ (father's education, mother's education, parental income, number of siblings, indicator for intact families, and PISA reading scores), a grade specific indicator (which allows the utility of attending school to vary with grade levels), initial schooling attainment at age $16\left(S_{i 0}\right)$, unobserved, time invariant heterogeneity $\left(a s^{k}\right)$ and i.i.d. normally distributed random shocks $\left(\varepsilon_{i t}^{S}\right)$.

The indicator function, $\mathrm{I}\left(S_{i t}=j\right.$ ) equals 1 if individual $i$ completes grade level $j$ in period $t$, and 0 otherwise, where $j=9,10, \ldots, 19$ and $k$ denotes the number of unobserved heterogeneity supports.

\footnotetext{
10 The time periods in the model are defined as academic years.
} 


\subsection{Utility of Working}

The instantaneous utility of working is defined by the following equation:

$$
U_{i t}^{w}=\ln \left(w_{i t}\right)=\beta_{1}^{w}+\beta_{s}^{w} S_{l i t}+\beta_{e}^{w} E_{i t}+\beta_{e s q}^{w} E_{i t}^{2}
$$

where $w_{i t}$ denotes the hourly wage rate for individual $i$ in period $t, \beta_{1}^{w}$ is the constant term in the wage equation, $\beta_{s}^{w}$ and $\beta_{e}^{w}$ represent the return to school and work experience, respectively, and $E_{i t}$ denotes accumulated work experience in period $t$. The wage equation parameters differ across gender and provinces. ${ }^{11}$

\subsection{Schooling Interruptions}

To conform more closely to empirical facts, we also allow for schooling interruptions. Due to the absence of information about the reasons for, and the activities during, the interruptions, we follow Belzil and Hansen (2002) and incorporate them as a state, which occurs with an exogenous probability, $\pi_{t} \cdot{ }^{12}$ If an interruption happens in a given period, the decision problem is frozen and the stock of schooling remains constant over that period until the beginning of the next one. Since we lack data on parental transfers and other income during interruptions, we do not distinguish the payoff the individual receives when in school from the payoff when school is interrupted.

\subsection{Value Functions}

At the beginning of each period, individuals choose between continuing to invest in schooling $\left(d_{i t}=1\right)$ or terminating schooling investments and entering the labor market $\left(d_{i t}=0\right)$. The decision to enter the labor market is assumed to be permanent. That is, $d_{i t}=0$ implies that $d_{j t}=0$ for all $j=t+1, \ldots, T$.

\footnotetext{
11 The wage function describes the expected log-wage an individual will receive in period $t$ given the stock of education and work experience at that time.

12 This probability is inferred from the proportion of school interrupters at each grade level and is assumed to be common to all respondents.
} 
The value of terminating schooling and entering the labor market in period $t$ is given by:

$$
V_{i t}^{w}\left(S_{i t}\right)=\ln \left(w_{i t}\right)+\delta V_{i, t+1}^{w}\left[\left(S_{i, t+1}\right) \mid d_{i t}=0\right]
$$

where $\delta$ is the discount factor and the second term on the right-hand side is simply the discounted value of working from period $t+1$ until retirement:

$$
V_{i, t+1}^{w}\left[\left(S_{i, t+1}\right) \mid d_{i t}=0\right]=\sum_{j=t+1}^{T} \delta^{j-(t+1)}\left\{\beta_{1}^{w}+\beta_{s}^{w} S_{l i j}+\beta_{e}^{w} E_{i j}+\beta_{e s q}^{w} E_{i j}^{2}\right\}
$$

The current discounted value of remaining in school at the beginning of period $t$ can be expressed by the following Bellman equation:

$$
\begin{aligned}
V_{i t}^{s}\left(S_{i t}, \Omega_{i t}\right)= & \bar{V}_{i t}^{s}+\varepsilon_{i t}^{s}+ \\
& \delta\left\{\pi_{t+1} E\left(V_{i, t+1}^{I}\right)+\left(1-\pi_{t+1}\right) E M A X\left[V_{i, t+1}^{s}\left(S_{i, t+1}, \Omega_{i, t+1}\right), V_{i, t+1}^{w}\left(S_{i, t+1}\right)\right]\right\}
\end{aligned}
$$

where

$$
\bar{V}_{i t}^{s}=\beta_{l} X_{l i t}+\alpha_{j}^{c} I\left(S_{i t}=j\right)+\alpha_{0}^{k} S_{i 0}+a s^{k}
$$

and where $S_{i t}$ represents educational attainment at beginning of period $t$. $\Omega_{i t}$ contains information on the individual's initial educational attainment $\left(S_{i 0}\right)$, observed characteristics, unobserved heterogeneity represented by the vector $\Theta \in\left(\alpha_{0}^{k}, a s^{k}, \varepsilon_{i t}^{s}\right)$ and accumulated work experience $\left(E_{i t}\right)$. The EMAX function on the right-hand side above is: 


$$
\begin{aligned}
\operatorname{EMAX}\left[V_{i, t+1}^{s}\left(S_{i, t+1}, \Omega_{i, t+1}\right), V_{i, t+1}^{w}\left(S_{i, t+1}\right)\right] & =\operatorname{Pr}\left(d_{i, t+1}=1\right) E\left(V_{i, t+1}^{s} \mid d_{i, t+1}=1\right)+ \\
& \operatorname{Pr}\left(d_{i, t+1}=0\right) V_{i, t+1}^{w}\left[\left(S_{i, t+1}\right) \mid d_{i, t+1}=0\right]
\end{aligned}
$$

Further, $V_{i, t+1}^{I}$ is the value of interrupting schooling in period $t+1$ and $\pi_{t+1}$ is the probability of such a schooling interruption. Specifically, the value of interrupting schooling is written as:

$$
\begin{aligned}
V_{i, t+1}^{I}\left(S_{i, t+1}, \Omega_{i, t+1}\right)= & \beta_{l} X_{l i, t+1}+\alpha_{j}^{c} I\left(S_{i, t+1}=j\right)+\alpha_{0}^{k} S_{i 0}+a s^{k}+\varepsilon_{i, t+1}^{s}+ \\
& \delta\left\{\pi_{t+2} E\left(V_{i, t+2}^{I}\right)+\left(1-\pi_{t+2}\right) E M A X\left[V_{i, t+2}^{s}\left(S_{i, t+2}, \Omega_{i, t+2}\right), V_{i, t+2}^{w}\left(S_{i, t+2}\right)\right]\right\}
\end{aligned}
$$

Finally, each value function is solved using backwards induction and an individual chooses to terminate schooling and enter the labor market permanently in period $t$ if

$$
V_{i t}^{s}\left(S_{i t}, \Omega_{i t}\right) \leq V_{i t}^{w}\left(S_{i t}\right)
$$

\subsection{Estimation}

The dynamic programming model presented above is solved using backward recursions and the parameters of the model are estimated using maximum likelihood techniques. The decision rule $d_{i t}, t \in\{0,1,2, \ldots, 11\}$, determines the transition path from school to work. ${ }^{13}$ To obtain a computationally practical expression, we assume that $\varepsilon_{i t}^{s}$ is identically and independently distributed as a normal random variable with a mean equal to 0 and a variance equal to $\sigma_{s}^{2}$. This assumption allows us to write the probability of remaining in school in period $t$ as:

$$
\operatorname{Pr}\left(d_{i t}=1\right)=\operatorname{Pr}\left(V_{i t}^{s}\left(S_{i t}, \Omega_{i t}\right)>V_{i t}^{w}\left(S_{i t}\right)\right)=\Phi\left(\frac{\left(V_{i t}^{s}\left(S_{i t}, \Omega_{i t}\right)-\varepsilon_{i t}^{s}\right)-V_{i t}^{w}\left(S_{i t}\right)}{\sigma^{s}}\right)
$$

\footnotetext{
13 For example, $d_{i 0}=0$ occurs when a respondent is not enrolled in school at age 16 .
} 
and the probability of leaving school permanently in period $t$ can be written as:

$$
\operatorname{Pr}\left(d_{i t}=0\right)=\operatorname{Pr}\left(V_{i t}^{s}\left(S_{i t}, \Omega_{i t}\right) \leq V_{i t}^{w}\left(S_{i t}\right)\right)=1-\Phi\left(\frac{\left(V_{i t}^{s}\left(S_{i t}, \Omega_{i t}\right)-\varepsilon_{i t}^{s}\right)-V_{i t}^{w}\left(S_{i t}\right)}{\sigma^{s}}\right)
$$

These probabilities can be calculated given the distributional assumptions of the time-varying utility shocks. The likelihood function consists of the probability of observing $\tau$ years of schooling, given by

$$
L_{i}=\operatorname{Pr}\left(d_{i, 0}=1, d_{i, 1}=1, \ldots, d_{i, \tau}=1, d_{i, \tau+1}=0\right)
$$

As mentioned above, it is possible that personal endowments that help explain schooling decisions beyond age 16 are also instrumental in determining how much schooling one has acquired by the age of 16 . A failure to account for this possibility could seriously bias the estimates of the structural parameters. We have explored this possibility and found that our parameters were not affected in any significant way when we endogenize initial schooling.

We also estimated a model that incorporated additional unobserved heterogeneity (in addition to $\varepsilon_{i t}^{s}$ ). Again, our results were robust to the inclusion of time-invariant unobserved heterogeneity.

\section{Data}

\subsection{Survey and Sample Selections}


In this paper we utilize data extracted from the Canadian Youth in Transition Survey (YITS). YITS is a longitudinal survey that was initiated in 1999. It collects information about major transitions in young people's lives, particularly those between education and work. Since the initial interview, follow-up interviews have been conducted every two years and the most recent interview (the fifth follow-up interview) took place in 2010. There are two different YITS cohorts: cohort A (consisting of a sample of respondents who were 15 years old in 1999) and cohort B (consisting of a sample of respondents who were between 18 and 20 years old in 1999). Further, respondents in cohort A also completed student achievement tests as part of the Programme for International Student Assessment (PISA).

In this paper, information from all available interviews (six cycles) for the youngest cohort (cohort A) is utilized. The empirical analysis requires information on educational attainment, which is obtained from longitudinal information on school enrollment. To be included in our sample, an individual respondent must have completed the PISA reading test in addition to having participated in all followup interviews, yielding a balanced panel of young individuals observed for 11 periods. ${ }^{14}$ These requirements reduced the sample from 29,687 to 10,859 individuals. Moreover, all individuals with incomplete information on any individual or family background variable were dropped. This further reduced the sample to 8,252 respondents.

We include test scores in the model in order to control for scholastic ability and to assess how much of educational differences in the sample are due to differences in cognitive skills. By including results from a series of standardized achievement tests taken by the respondents in the first wave of the survey, YITS offer a unique opportunity to control for cognitive abilities. However, there is variation in the sample in highest-grade level completed at the time the test was administered. Thus, we need to purge the test scores from educational attainment

\footnotetext{
${ }^{14}$ The main reason for using a balanced panel is to enable the use of sample weights. Using sample weights in unbalanced samples is not trivial since the weights are adjusted in each cycle to reflect attrition and other changes in sample characteristics across cycles. We are cognizant of the fact that attrition from the sample may be non-random and consequently impact our estimated preference parameters.
} 
before including them in the model since failing to do this will generate biased and inconsistent estimates. We overcome this problem by replacing actual, unadjusted test scores with residuals from regressions of test scores on educational attainment at the time of the test.

\subsection{Educational Attainment}

Information on educational attainment is obtained from monthly full-time school enrolment records. Further, by utilizing information on monthly full-time student status and the date of birth, we are able to calculate the highest grade completed for each respondent and each academic year after the age of 16.

Tables 1 and 2 show the distribution of the highest grade completed as of December 2009, by province for males and females, respectively. The entries in the tables illustrate provincial differences in educational attainment, differences that reflect disparities in the institutional structure of educational systems across provinces. For example, in Quebec students complete their secondary education after grade 11. In all other provinces, completion of secondary school coincides with completing grade 12.15

The effect of the shorter elementary/secondary school program in Quebec is present in Table 1. The proportion of males who have completed grade 11 but not grade 12 is much higher in Quebec than in any other province (except for Alberta).

The entries in Table 1 also provide some insight into current high school dropout rates in Canada. According to Table 1, this rate varies from around 6 percent in Nova Scotia and New Brunswick to over 20 percent in Alberta. ${ }^{16}$ The dropout rates in Table 1 are similar to those published recently by Statistics Canada (Gilmore (2010) and McMullen and Gilmore (2010)).

\footnotetext{
${ }^{15}$ A reform in the late 1990s in Ontario reduced the length of the secondary program from five years to four years. The cohort that entered high school in 1999-2000 was the first class to graduate from the new four-year program. Consequently, the 2002-03 school year saw the graduation of two cohorts of students, the last cohort from the five-year program and the first cohort from the fouryear program.

16 The high school dropout rate may be inferred from the fraction of students that have not completed grade 12 (grade 11 for Quebec).
} 
The proportion of young males that have acquired any PSE also varies across provinces. ${ }^{17}$ It is lowest in the Prairies (50-56 percent in Manitoba, Saskatchewan and Alberta) and highest in Nova Scotia, Quebec and Ontario (70-77 percent).

Table 2 shows the distribution of educational attainment across provinces for female youths. Generally, the high school dropout rates are lower and participation rates in post-secondary education are higher than for males. Similar to the pattern for males, the incidence of post-secondary education is lowest in the Prairies (and in British Columbia) and highest in Quebec and Ontario.

\subsection{Wages}

Although there is wage information available in YITS, we utilize wage data from the 2000 Canadian Census instead. The main reason for not using YITS wages is that they, for most respondents, represent either part-time wages (obtained while enrolled in school) or early labor market wages. These wages are generally not representative of the compensation educated workers receive over the life cycle and will therefore underestimate wage differences across educational attainment. Moreover, it is likely that the wage expectations students have differ from these entry or part-time wages. Thus, we collect data on earnings, hours of work, education and age from the 2000 Census and regress hourly wages (created by dividing earnings with hours of work) on education and work experience (approximated as age - education - 6). The estimated regression parameters (available upon request) are used to obtain the expected value of work conditional on a given level of education, which is needed to solve the dynamic programming problem.

The regression results generally suggest a higher association between education and wages for females than for males. On the other hand, wages appear to grow faster with experience for males than for females.

\footnotetext{
17 For students in all provinces except for Quebec, we define PSE as completion of grade 13 or above. For Quebec students, we consider the two-year College d'enseignement general et professional (CEGEP) program as post-secondary education.
} 


\subsection{Descriptive Statistics}

Table 3 provides a profile of youths in Canada by highlighting differences in selected observable characteristics between high school dropouts, high school graduates, and those with at least some post-secondary education (PSE). ${ }^{18}$ The gender difference in educational attainment is again shown since the high school dropout rate is higher for males (11 percent) than for females (7 percent). Further, the proportion of respondents with some PSE is lower for males (68 percent) than for females (78 percent). The link between PISA reading scores and schooling is clear, both for males and females. Interestingly, the average female score on the reading test is higher then the male average. Number of siblings is negatively related to schooling but only for males. The variable nuclear family equals one if the respondent lived with both biological parents most of the time during high school and has been found to be an important determinant of school attendance in previous studies (e.g. Belzil and Hansen (2002) and Belzil and Hansen (2006)). This pattern is also confirmed in our sample as nuclear family appears to be correlated with educational attainment.

Differences in parents' education, both mother's and father's, may also explain school attendance and completion. Previous research has documented significant intergenerational correlations in educational attainment, both in Canada and elsewhere. Such a relationship can also be observed in Table 3, for both males and females. The last entries in Table 3 illustrate the link between educational attainment and parental income. For both males and females, average parental income is lowest for high school dropouts and highest for youths with some PSE.

To further analyze the relationship between parental income, parent's education and educational attainment we estimate a number of linear regression models. Tables 4 and 5 show results from these regressions where the dependent variable is highest grade completed. In the first column, we only include parental income as an explanatory variable. The coefficients equal 0.005 for males and 0.008

\footnotetext{
${ }^{18}$ As described above, we infer high school graduation status as well as PSE status from reported highest grade completed, adjusting for the different requirements in Quebec. As a result, we overestimate the proportion of PSE participants in Ontario as some respondents belonged to a cohort who was required to complete a five-year high school program.
} 
for females and are statistically significant. However, the magnitudes of the estimates are small. ${ }^{19}$

In the second column, we add controls for father's education (measured by two indicator variables, one for completed high school and one for education beyond high school). As expected, the coefficients are positive and significant suggesting a positive relationship between children's and parents' education. The estimates also suggest that the relationship is economically significant. The inclusion of controls for father's education reduced the coefficient on parental income from 0.005 to 0.004 . The third column shows results when we also add controls for mother's education. As for father's education, the relationship between children's education and mother's education is positive and significant, both in an economic and statistical sense.

A control for scholastic ability (using the PISA reading score) is added to the regressors in the fourth column. The estimate is positive and significant and suggests that a 100-point increase in the reading score increases educational attainment with about one year. ${ }^{20}$ With the addition of the reading score, the estimates associated with parental income and parent's education are reduced. Finally, we add controls for other observable family characteristics (number of siblings, nuclear family, visible minority status and urban) as well as provincial indicators. Addition of the variables does not change the estimates of parental income and parent's education in any significant way.

Table 5 shows the regression results for the female sample and overall the regression coefficients are similar to those obtained using the male sample.

\section{Results ${ }^{21}$}

\footnotetext{
19 Parental income is expressed in $\$ 10,000$.

20 The difference in average reading scores between high school dropouts and those with some PSE is around 70 points for both males and females, see Table 3.

21 The results presented in this section are based on a model specification that ignores permanent unobserved heterogeneity. We have obtained results for a two-type specification of unobserved heterogeneity for males and the estimated preference parameters (and simulation results) are very similar to those of the restricted model that ignores permanent unobserved heterogeneity. For females, we have encountered numerical problems and have been unable to obtain convergence.
} 


\subsection{Model fit}

Before analyzing the effects of changes in observed characteristics and performing policy simulations, we validated the model by comparing predictions generated by the model with the observed schooling distributions, both for males and females. The results are shown in Table 6. In both cases, the two distributions are very similar. For example, according to the data, 9.1 percent of males and 6.0 percent of females have completed less than grade 12 . These numbers according to our model are 8.6 percent and 6.1 percent for males and females, respectively. Further, in the data, 18.5 percent of males and 12.5 percent of females have completed grade 12. Again, the model predictions are close, 19.4 percent and 11.6 percent, respectively. Lastly, the actual and predicted proportions of students with some PSE (grade 13 or above) are 72.5 percent and 71.9 percent, respectively for males and 81.5 percent and 82.4 percent, respectively for females.

We also regressed predicted educational attainment on a set of observed characteristics to determine how much of the overall variation in generated schooling can be explained by different observed characteristics. The entries in Table 7 show that two percent of the variation in predicted schooling can be explained by variation in parental income for male students. Adding controls for father's education raise the adjusted R-square value to 0.078 , suggesting that father's education explains an additional six percent of the variation. When we add controls for mother's education, the adjusted R-square equals 0.092. Next we added a control for PISA Reading Test scores which increased the adjusted R-square value to 0.192 . This suggests that reading ability explains 10 percent of the overall variation in predicted education, after controlling for parental education and income. Lastly, we added controls for number of siblings, an indicator for broken home and provincial controls. This raised the adjusted R-square to 0.224 .

From this exercise, we conclude that parental education and reading ability are the main factors that determine the explained variation in schooling attainment and that parental income has a relatively small impact. This finding is similar to that reported in Belzil and Hansen (2003) for U.S. data. They reported that about one third of the explained variation is due to scholastic ability and two-thirds to family 
background characteristics (mainly parental education). Our results suggest that about half of the explained variation is due to scholastic ability and the other half is due to family background. The results for the female sample are similar to the ones for males with one difference; mother's education explains a greater share of the total variation for female students than for male students.

\subsection{Policy Simulations}

One of the main advantages of estimating a structural model of educational decisions is that it allows the researchers to analyze how educational attainment is affected by changes in observable characteristics, such as parental education and family income. Further, with such a model it is possible to compare expected outcomes under alternative policies. In this section we describe expected impacts on educational attainment from a number of counterfactual experiments. In all cases, we compare the distribution of educational attainment that the model generates using observed characteristics and estimated parameters with a distribution that is obtained when we change a student's family background or modify the cost of completing a certain grade level.

\subsubsection{Parental Income and Income Support}

As mentioned earlier, there is much interest in the relationship between parental income and educational attainment. We further explore this issue by simulating outcomes using observed levels of parental income and income levels that have been counterfactually increased. Specifically, we consider two experiments. In the first, we increase parental income by 25 percent for everyone while in the second experiment we increase parental income with one standard deviation. ${ }^{22}$

The results in Table 8 suggest that the effect on an increase in parental income on educational attainment is very modest, even though the estimated parameters associated with parental income are statistically significant. In

\footnotetext{
22 This will enable us to compare the magnitudes of changes in schooling when we counterfactually
} increase parental income and PISA reading scores. 
particular, increasing parental income with 25 percent will hardly have any impact on the schooling distribution of males. The estimated reactions are slightly larger for female students whose PSE enrollment will increase by 1 percent. Moreover, high school dropout rates will drop slightly, 1.3 percent for male students and 3.3 percent for female students.

Increasing parental income by a percentage may however not be the most appropriate way to illustrate the impact of increased parental resources on educational attainment since this increases income levels more for students with wealthy parents than for students with poorer parents. To address this, we analyzed how an increase in parental income for everyone by a fixed amount (one standard deviation corresponding to around $\$ 5,000$ for both males and females) would change educational outcomes.

For males, the change is minor and only slightly larger than the changes that were observed when we increased parent's income for everyone with 25 percent. In particular, PSE attendance increases by 2.1 percent while the high school dropout rate will drop by 0.4 percentage points, from 8.8 percent to 8.4 percent. For female students, the changes in educational outcomes are somewhat larger than for males. PSE attendance will increase by 3.2 percent and the high school dropout rate will drop by 0.9 percentage points to 5.8 percent.

Overall, these results are consistent with the regression results presented in the section above, which showed that only a small portion of the observed variation in educational attainment can be explained by differences in parental income. Providing large monetary transfers to parents appear to have limited effects on educational attainment. Assuming that these increases in parental income are transferred to students, these results suggest that financial constraints are not a major issue in preventing access to higher education for Canadian youth. This result is consistent with findings in the U.S. literature (see Cameron and Heckman (1998 and 2001), Carneiro and Heckman (2002) and Cameron and Taber (2004)) which suggest that long-term factors, such as parental education, scholastic ability and unobserved heterogeneity, are more important than parental income in determining educational investment decisions. 


\subsubsection{Tuition Fees and Subsidies}

Current tuition fees in Canada are relatively low compared to the U.S. However, over the past 20 years, the fees have increased in most provinces and for the 2011/2012 academic year, the average tuition fee, across disciplines and provinces, is $\$ 5,366 .{ }^{23}$ Fees are generally lowest in Quebec (average of $\$ 2,519$ ) and highest in Ontario (average of $\$ 6,640$ ). Further, there are substantial differences across disciplines, with dentistry and medicine being the most expensive fields and humanities and social sciences being the least expensive. We use our model to illustrate the effects of increasing annual tuition fees for grades 13 and above with $\$ 2,500$. The results are presented in Table 9. PSE attendance is predicted to decrease with 12 percent (or 8 percentage points) for males and with 8 percent (or 6.5 percentage points) for females. Most of the students who will no longer find PSE attractive will now stop at grade 12 .

These results indicate that financial resources, other than parental income, play a role in PSE enrollment and that attendance will drop as fees increase. However, the magnitudes of the reactions are relatively small considering the simulated fee increase. Nevertheless, our findings suggest that youths respond to changes in current costs and that policy makers may want to review the availability of bursaries and subsidized loans to offset the reduction in attendance following fee increases.

We also explored the characteristics of the students who are predicted to change their educational attainment as a result of a fee increase. In particular, we regressed an indicator for a change in predicted education on observed characteristics. The regression estimates reveal that the reactions are unrelated to parental income (the point estimates are close to zero and not statistical significant at conventional significance levels) for both males and females.

To further analyze the role of income support while attending higher education, we simulate the effect on schooling from a $\$ 2,500$ subsidy (per grade

\footnotetext{
${ }^{23}$ Source: Statistics Canada, Centre for Education Statistics.
} 
level for grades 13 and above) for poor students. ${ }^{24}$ The results are presented in Table 10 and as can be seen in columns one and four, PSE attendance is lower and high school dropout rates are higher among these students. The subsidy is predicted to increase PSE enrollment with nine percent for both males and females.

Finally, we used our model to assess the proposed tuition fee increase in Quebec. Our results suggest that the $\$ 1,625$ increase will reduce university attendance by a modest 3.2 percent for male students and by 2.1 percent for females. Further, the reductions are not significantly related to observable characteristics, such as parental education and income. Thus, we find no support for the concerns that have been raised by some student associations that the increase will disproportionately affect students from poor families.

\subsubsection{PISA Reading Scores}

While changes in parental income was shown to have a limited impact on schooling outcome, the effect of changes in PISA reading scores are much larger. As an illustration, an increase of the test scores with one standard deviation reduces the high school dropout rates with around 40 percent for both males and females, see Table 11. The standard deviation equals 91 for males and 84 for females and in both cases the increase corresponds to the difference in mean test scores between those with some PSE (grade 13 or more) and high school dropouts (grade 11 or less).

However, an overall increase in test scores by such a magnitude may seem both unrealistic and difficult to implement. As an alternative to this experiment, we considered the effects from increasing reading scores for those who had a score lower than 500 to 500. This is a more modest ambition that would impact fewer students, in particular female students (where the mean score for high school dropouts is 496). The results from this simulation are presented in columns four to six in Table 11. As shown in column four, average educational attainment is much lower among these low-scoring students than among all students. The predicted

\footnotetext{
${ }^{24}$ We define poor students as those whose parental income is in the lowest quartile of the parental income distribution.
} 
effects of increasing the test scores to 500 for these students are shown in columns five and six. The high school dropout rate will decline by 31 percent for males and 23 percent for females and PSE attendance will increase by 21 and 8 percent, respectively for males and females.

Overall, the responses from changes in PISA reading scores are substantially larger than those observed when we counterfactually increase parental income. These results clearly illustrate that scholastic ability play a more important role in determining educational success than parental income. Again, this finding is consistent with U.S. evidence (i.e. Cameron and Heckman (1998 and 2001) and Carneiro and Heckman (2002)).

\subsubsection{Increase in Father's Education}

Previous studies have found significant relationships between the education of parents and the educational attainment of their children. Our structural estimates also indicate the existence of such a relationship and in order to further explore this, we counterfactually set father's education equal to grade 13 or more. This meant that we increased father's education for 39 percent of male students and for 37 percent of female students.

The results are shown in Table 12. This increase in father's education is predicted to reduce high school dropout rates by 15 percent for males and 20 percent for females. Further, the PSE attendance will increase with 4.8 percent for males and 3.2 percent for females. These estimated impacts are larger than those reported for the income changes above and illustrate the importance of long-term factors. While the increase in father's education that we simulated may not be a viable policy option, the results show the importance of parental education on children's schooling choices. This has been documented numerous times in the literature.

\subsubsection{Future wages}

Our model assumes that students are forward-looking when making schooling decisions and that they consider the impact of schooling on future wage 
outcomes. This feature of the model enables us to explore how changes in the return to education will affect educational attainment. In a counterfactual simulation, we raised the return to education by 25 percent. These increases increased PSE attendance for males by 3 percent and for females with 4 percent, see Table 13 . These numbers are similar to those reported above where we increased father's education. A higher return to education will also reduce the high school dropout rates, by 13 percent for males and 27 percent for females.

Our results are consistent with those in Gunderson and Krashinsky (2009) who find that Canadian students consider expected future earnings when choosing fields of study. The findings in Table 13 are also consistent with Belzil and Hansen (2006). They find that educational attainment in Canada increase significantly as expected future earnings increase. This effect is grade level dependent and the largest impact is found for grade levels beyond high school.

\section{Summary}

In this paper, we develop and estimate a structural, dynamic model of schooling decisions using data extracted from the Canadian Youth in Transition Survey (YITS). The model incorporates forward-looking behavior and expectations about future benefits from investing in education.

We use the model to provide evidence on the role of family background variables, cognitive achievement and future wages in shaping schooling attainment in Canada. Moreover, we evaluate a counterfactual policy alternative aimed at increasing the direct costs of attending higher education.

Before analyzing the effects of changes in observed characteristics and performing counterfactual policy simulations, we validate the model by comparing predictions generated by the model with the observed schooling distributions, both for males and females. In both cases, the two distributions are very similar.

The results from our simulations suggest that the effect of an increase in parental income on educational attainment is very modest. Our simulations further show that the educational distributions significantly depend on cognitive 
achievements, parental education and increased returns to schooling. These results are consistent with findings in the U.S. literature (see for example Cameron and Heckman (1998 and 2001), Carneiro and Heckman (2002) and Cameron and Taber (2004)) which suggest that long-term factors, such as parental education, scholastic ability and unobserved heterogeneity, are more important than parental income in determining educational investment decisions.

However, this literature also argue that financial constraints do not play a major role in determining educational attainment. To the extent that this can be inferred from parental income, our results are consistent with the U.S. evidence. But, as we showed above, when we modify the monetary equivalent of the instantaneously utility of attending school, we see changes in the predicted schooling distribution that exceed those obtained when we modify parents income. If we reduce the utility by the equivalent of $\$ 2,500$, our model predicts that PSE attendance will drop by 12 and 8 percent, respectively for males and females. While these reactions exceed those we obtain when we change parental income, they are relatively modest considering the magnitude of the fee increase (which corresponds to around 50 percent of the current Canadian average).

We believe our results will provide new and valuable insights into the issue of access to higher education and the role of financial constraints. Most of the existing studies on access to higher education in Canada have relied on multivariate regressions (linear or non-linear). The regression results can be used to infer partial correlations between selected observed characteristics, such as parental income, and educational attainment. However, the effect of monetary transfers to students or fee increases can neither be identified nor estimated in these types of models. Instead, a carefully constructed structural model that recognizes the role of current cost or utility is required and this is what we provide in this paper.

Apart from the simulation exercises we have conducted in this paper, the model we have estimated can be used to analyze the compensation levels that would be required to prevent certain students from dropping out of high school (or PSE) or to quantify the option values associated with different grade levels. We plan on investigating these issues in the near future. 


\section{References}

Attanasio, O., C. Meghir and A. Santiago, 2005, "Education Choices in Mexico: Using a Structural Model and a Randomized Experiment to Evaluate Progresa," Working Paper, University College London.

Bauer, P. and R. Riphahn, 2007, "Heterogeneity in the Intergenerational

Transmission of Educational Attainment: Evidence from Switzerland on Natives and Second Generation Immigrants," Journal of Population Economics, Vol. 20, 121-48.

Belley, P., Frenette, M. and L. Lochner, 2011, “Post-Secondary Attendance by Parental Income in the U.S. and Canada: What Role for Financial Aid Policy?" NBER Working Paper No. 17218.

Belzil, C. and J. Hansen, 2002, "Unobserved Ability and the Return to Schooling," Econometrica, 70 (5), 2075-91.

Belzil, C. and J. Hansen, 2003, "Structural Estimates of the Intergenerational Education Correlation," Journal of Applied Econometrics, 18 (6), 679-96.

Belzil, C. and J. Hansen, 2006, "Educational attainment in Canada: Effects of individual attributes and expected outcomes," HISSRI Working Paper 2006 C-11.

Belzil, C. and J. Hansen, 2007, "A Structural Analysis of the Correlated Random Coefficient Wage Regression Model," Journal of Econometrics, 140 (2), 827-48.

Bowlby, G. and K. McMullen, 2005, "Provincial drop-out rates - Trends and consequences", Education Matters: Insights on Education, Learning and Training in Canada, Vol. 2, No. 4, Statistics Canada. 
Cameron, S. and J.J. Heckman, 1998, "Life Cycle Schooling and Dynamic Selection Bias: Models and Evidence for Five Cohorts of American Males," Journal of Political Economy, 106, 262-333.

Cameron, S. and J.J. Heckman, 2001, "The Dynamics of Educational Attainment for Black, Hispanic and White Males," Journal of Political Economy, 109, 455-99.

Cameron, S. and C. Taber, 2004, "Estimation of Educational Borrowing Constraints Using Returns to Schooling," Journal of Political Economy, 112, 132-82.

Carneiro, P. and J.J. Heckman, 2002, "The Evidence on Credit Constraints in PostSecondary Schooling," Economic Journal, 112, 989-1018.

Christofides, L.N., Cirello, J. and M. Hoy, 2001. "Family income and post-secondary education in Canada," Canadian Journal of Higher Education, Vol. 31, 177-208.

Coelli, M., 2005, "Parental income shocks and the education attendance of youth," Working Paper, University of British Columbia.

Corak, M., Lipps, G. and J. Zhao, 2005, "Family income and participation in postsecondary education," In C. Beach, R. Boadway, and M. McInnis (editors), Higher Education in Canada. Montreal: John Deutsch Institute and McGill-Queen's Press.

Deming, D., and S. Dynarski, 2009, "Into College, Out of Poverty? Policies to Increase the Postsecondary Attainment of the Poor", NBER Working Paper No. 15387.

Drolet, M., 2005, "Participation in post-secondary education in Canada: Has the role of parental income and education changed over the 1990s?," Research Paper, Statistics Canada. 
Dynarski, S., 2003, “Does Aid Matter? Measuring the Effect of Student Aid on College Attendance and Completion", American Economic Review, 93(1), 279-88.

Eckstein, Z. and K. Wolpin, 1999, "Why Youths Drop Out of High School: The Impact of Preferences, Opportunities, and Abilities," Econometrica, 67, 1295-1339.

Ermisch, J. and M. Francesconi, 2001, "Family matters: Impacts of family background on educational attainments," Economica, Vol. 68, 137-56.

Finnie, R., Lascelles, E. and A. Sweetman, 2005, "Who goes? The direct and indirect effects of family background on access to post-secondary education," Research Paper, Statistics Canada.

Frenette, M., 2003, "Access to college and university: Does distance matter?," Research Paper, Statistics Canada.

Frenette, M., 2005, "The impact of tuition fees on university access: Evidence from a large-scale price deregulation in professional programs," Research Paper, Statistics Canada.

Frenette, M., 2007, “Why are Youth from Lower-Income Families Less Likely to Attend University? Evidence from Academic Abilities, Parental Influences, and Financial Constraints", Statistics Canada, Analytical Studies Branch Research Paper No. 295.

Frenette, M. and K. Zeman, 2007, “Why Are Most University Students Women? Evidence Based on Academic Performance, Study Habits and Parental Influences," Research Paper, Statistics Canada. 
Gilmore, J., 2010, "Trends in dropout rates and the labour market outcomes of young dropouts," Education Matters: Insights on Education, Learning and Training in Canada, vol. 7, No. 4, Statistics Canada.

Gunderson, M. and H. Krashinsky, 2009, Do Education Decisions Respond to Returns by Field of Study?," CLSRN Working Paper No. 47.

Hansen, J., X.F. Liu and M. Kucera, 2011a, "Educational Attainment of Children of Immigrants: Evidence from Two Cohorts of American Youths," Working Paper, Concordia University.

Hansen, J., X.F. Liu and M. Kucera, 2011b, "Disparities in Schooling Choices and Wages Between Ethnic Minorities and Whites: Evidence from the NLSY97," Working Paper, Concordia University.

Haveman, R. and B. Wolfe, 1995, "The determinants of children's attainments: A review of methods and findings," Journal of Economic Literature, Vol. 33, 1829-78.

Kane, T., 1994, "College Attendance by Blacks since 1970: The Role of College Cost, Family Background and the Returns to Education," Journal of Political Economy, 102 (5), 878-911.

Kane, T., 2006, "Public Intervention in Post-Secondary Education," in E. Hanushek and F. Welch (eds.), Handbook of the Economics of Education, Vol. 2, Ch. 23, Amsterdam: Elsevier Science.

Keane, M, 2010, "A Structural Perspective on the Experimentalist School," Journal of Perspective Economics, 24, 47-58.

Keane, M. and K. Wolpin, 1997, "The Career Decisions of Young Men," Journal of Political Economy, 105, 473-522. 
Keane, M. and K. Wolpin, 2001, "The Effect of Parental Transfers and Borrowing Constraints on Educational Attainment," International Economic Review, 42, 10511103.

Kucera, M., 2008, "The Educational Attainment of Second Generation Immigrants in Canada: Analysis based on the General Social Survey," Working paper, Learning Policy Directorate, HRSDC.

Lauer, C., 2003, "Family background, cohort, and education: A French-German comparison based on a multivariate ordered Probit model of educational attainment, Labour Economics, Vol. 10, 231-51.

Liu, X., 2011, "Educational Attainment of Second-Generation White Immigrants: A Comparison Between the U.S. and Canada," Working Paper, Concordia University.

Lucas, S.R., 2001, “Effectively Maintained Inequality: Education Transitions, Track Mobility, and Social Background Effects," American Journal of Sociology, Vol. 106, 1642-90.

Mare, R. D., 1980, “Social Background and School Continuation Decisions," Journal of the American Statistical Association, Vol. 75, 295-305.

McIntosh, J. and M. Munk, 2007, "Scholastic ability vs family background in educational success: Evidence from Danish sample survey data," Journal of Population Economics, Vol. 20, 101-20.

McMullen, K. and J. Gilmore, 2010, "A Note on High School Graduation and School Attendance, by Age and Province, 2009/2010," Education Matters: Insights on Education, Learning and Training in Canada, vol. 7, No. 4, Statistics Canada. 
Myers, K. and P. de Broucker, 2006, “Too Many Left Behind: Canada's Adult Education and Training System," Research Report W|34, Canadian Policy Research Networks.

Parent, D., 2006, "Work while in high school in Canada: its labor market and educational attainment effects", Canadian Journal of Economics Vol. 39, 1125-50.

Rivard, M. and M. Raymond, 2004, "The Effect of Tuition Fees on Post-Secondary Education in Canada in the late 1990s," Working Paper, Department of Finance, Government of Canada.

Rumberger, R.W. and S. P. Lamb, 2003, "The Early Employment and Further Education Experiences of High School Dropouts: a Comparative Study of the United States and Australia," Economics of Education Review, Vol. 22, 353-66.

Sun, M., 2008, "A Dynamic Analysis of Education in Canada: Evidence from the YITS," MA paper, Department of Economics, Concordia University.

Thiessen, V., 2007, "The impact of factors on trajectories that lead to noncompletion of high school and lack of post-secondary education among those with high reading competencies at age 15," Report prepared for Human Resource and Social Development Canada (HRSDC).

Todd, P. and K. I. Wolpin, 2006, "Assessing the Impact of a School Subsidy Program in Mexico Using Experimental Data to Validate a Dynamic Behavioral Model of Child Schooling," American Economic Review, 96, 1384-1417.

Tyler, J. H., R. J. Murnane and J. B. Willett, 2000, "Do the Cognitive Skills of School Dropouts Matter in the Labor Market?," Journal of Human Resources Vol. 35, 748-54. 
Table 1. Distribution of the highest grade completed for males as of December 2009.

\begin{tabular}{lcccccccccc} 
& $\begin{array}{c}\text { New } \\
\text { foundland }\end{array}$ & P.E.I. & $\begin{array}{c}\text { Nova } \\
\text { Scotia }\end{array}$ & $\begin{array}{c}\text { New } \\
\text { Brunswick }\end{array}$ & Quebec & Ontario & Manitoba & $\begin{array}{c}\text { Saskat- } \\
\text { chewan }\end{array}$ & $\begin{array}{c}\text { British } \\
\text { Alberta }\end{array}$ \\
\hline $\begin{array}{l}\text { Grade 10 } \\
\text { or less }\end{array}$ & n.a. & n.a. & 0.01 & n.a. & 0.13 & n.a. & n.a. & n.a. & 0.02 & n.a. \\
Grade 11 & 0.09 & 0.09 & 0.05 & 0.06 & 0.17 & 0.10 & 0.12 & 0.12 & 0.19 & 0.08 \\
Grade 12 & 0.24 & 0.24 & 0.24 & 0.29 & 0.10 & 0.14 & 0.37 & 0.32 & 0.28 & 0.36 \\
Grade 13 & 0.16 & 0.18 & 0.17 & 0.18 & 0.14 & 0.18 & 0.18 & 0.14 & 0.12 & 0.16 \\
Grade 14 & 0.14 & 0.11 & 0.15 & 0.12 & 0.13 & 0.10 & 0.10 & 0.11 & 0.10 & 0.10 \\
Grade 15 & 0.12 & 0.09 & 0.11 & 0.11 & 0.08 & 0.15 & 0.06 & 0.06 & 0.08 & 0.07 \\
Grade 16 & 0.25 & 0.30 & 0.26 & 0.25 & 0.25 & 0.34 & 0.16 & 0.25 & 0.21 & 0.23 \\
or more & & & & & & & & & &
\end{tabular}

Note: All figures are weighted using sample weights provided by Statistics Canada.

For entries with n.a. there were not enough observations for results to be released.

Source: Youth in Transition Survey (YITS). 
Table 2. Distribution of the highest grade completed for females as of December 2009.

\begin{tabular}{|c|c|c|c|c|c|c|c|c|c|c|}
\hline $\begin{array}{l}\text { Highest } \\
\text { grade } \\
\text { completed }\end{array}$ & $\begin{array}{c}\text { New } \\
\text { foundland }\end{array}$ & P.E.I. & $\begin{array}{l}\text { Nova } \\
\text { Scotia }\end{array}$ & $\begin{array}{c}\text { New } \\
\text { Brunswick }\end{array}$ & Quebec & Ontario & Manitoba & $\begin{array}{l}\text { Saskat- } \\
\text { chewan }\end{array}$ & Alberta & $\begin{array}{c}\text { British } \\
\text { Columbia }\end{array}$ \\
\hline $\begin{array}{l}\text { Grade } 10 \\
\text { or less }\end{array}$ & n.a. & n.a. & n.a. & n.a. & 0.09 & n.a. & n.a. & 0.03 & n.a. & n.a. \\
\hline Grade 11 & 0.03 & 0.03 & 0.08 & 0.05 & 0.10 & 0.05 & 0.07 & 0.09 & 0.18 & 0.06 \\
\hline Grade 12 & 0.17 & 0.14 & 0.16 & 0.15 & 0.09 & 0.10 & 0.27 & 0.22 & 0.24 & 0.27 \\
\hline Grade 13 & 0.21 & 0.17 & 0.12 & 0.22 & 0.11 & 0.09 & 0.16 & 0.16 & 0.11 & 0.19 \\
\hline Grade 14 & 0.12 & 0.12 & 0.15 & 0.09 & 0.15 & 0.09 & 0.10 & 0.10 & 0.12 & 0.08 \\
\hline Grade 15 & 0.09 & 0.10 & 0.08 & 0.08 & 0.11 & 0.13 & 0.09 & 0.11 & 0.08 & 0.09 \\
\hline $\begin{array}{l}\text { Grade } 16 \\
\text { or more }\end{array}$ & 0.38 & 0.44 & 0.41 & 0.41 & 0.35 & 0.53 & 0.31 & 0.30 & 0.28 & 0.31 \\
\hline
\end{tabular}

Note: All figures are weighted using sample weights provided by Statistics Canada.

For entries with n.a. there were not enough observations for results to be released.

Source: Youth in Transition Survey (YITS). 
Table 3. Descriptive statistics, by educational attainment, as of December 2009.

\begin{tabular}{|c|c|c|c|c|c|c|}
\hline \multirow[b]{2}{*}{ Variable } & \multicolumn{3}{|c|}{ Males } & \multicolumn{3}{|c|}{ Females } \\
\hline & $\begin{array}{l}\text { Grade less } \\
\text { than } 12\end{array}$ & Grade 12 & $\begin{array}{l}\text { Grade } 13 \\
\text { and more }\end{array}$ & $\begin{array}{l}\text { Grade less } \\
\text { than } 12\end{array}$ & Grade 12 & $\begin{array}{l}\text { Grade } 13 \\
\text { and more }\end{array}$ \\
\hline Number of persons & 667 & 1340 & 1946 & 533 & 1091 & 2460 \\
\hline Proportion (\%) & 11 & 21 & 68 & 7 & 15 & 78 \\
\hline PISA reading score & 468 & 490 & 539 & 496 & 511 & 569 \\
\hline Urban & 0.67 & 0.69 & 0.76 & 0.66 & 0.62 & 0.74 \\
\hline Number of siblings & 1.51 & 1.48 & 1.44 & 1.37 & 1.35 & 1.43 \\
\hline Nuclear family & 0.8 & 0.84 & 0.89 & 0.76 & 0.8 & 0.9 \\
\hline \multicolumn{7}{|l|}{ Father's education: } \\
\hline Less than high school & 0.28 & 0.18 & 0.1 & 0.26 & 0.26 & 0.11 \\
\hline High school & 0.3 & 0.3 & 0.23 & 0.35 & 0.29 & 0.21 \\
\hline Post-secondary school & 0.42 & 0.52 & 0.67 & 0.39 & 0.45 & 0.68 \\
\hline \multicolumn{7}{|l|}{ Mother's education: } \\
\hline Less than high school & 0.24 & 0.1 & 0.07 & 0.21 & 0.18 & 0.08 \\
\hline High school & 0.34 & 0.37 & 0.31 & 0.4 & 0.36 & 0.29 \\
\hline Post-secondary school & 0.42 & 0.53 & 0.62 & 0.39 & 0.46 & 0.63 \\
\hline $\begin{array}{l}\text { Parental income in } 2000 \\
(\$ 1,000)\end{array}$ & 72.2 & 71.9 & 80.7 & 57.1 & 64.9 & 79.9 \\
\hline
\end{tabular}

Note: All figures are weighted by sample weights provided by Statistics Canada.

Source: Youth in Transition Survey (YITS). 
Table 4. OLS regression results for males.

Dependent variable: Highest grade completed

\begin{tabular}{|c|c|c|c|c|c|c|}
\hline Independent variable & (1) & $(2)$ & (3) & (4) & (5) & $(6)$ \\
\hline Parental income & 0.005 (6.9) & $0.004(5.1)$ & $0.003(5.0)$ & $0.002(3.3)$ & $0.002(3.3)$ & $0.002(3.3)$ \\
\hline \multicolumn{7}{|l|}{ Father's education: } \\
\hline High school & & $0.85(6.7)$ & $0.66(5.1)$ & $0.53(4.4)$ & $0.51(4.3)$ & $0.49(4.3)$ \\
\hline Above high school & & $1.50(13.3)$ & $1.20(10.0)$ & $0.92(8.1)$ & $0.85(7.6)$ & $0.84(7.7)$ \\
\hline \multicolumn{7}{|l|}{ Mother's education: } \\
\hline High school & & & $0.59(4.2)$ & $0.48(3.7)$ & $0.42(3.3)$ & $0.31(2.4)$ \\
\hline Above high school & & & $0.93(6.8)$ & $0.72(5.6)$ & $0.68(5.3)$ & $0.62(5.0)$ \\
\hline PISA reading score & & & & $0.01(20.0)$ & $0.01(20.0)$ & $0.01(30.0)$ \\
\hline $\begin{array}{l}\text { Controls for other } \\
\text { family background } \\
\text { variables }\end{array}$ & No & No & No & No & Yes & Yes \\
\hline $\begin{array}{l}\text { Controls for province } \\
\text { of residence }\end{array}$ & No & No & No & No & No & Yes \\
\hline
\end{tabular}

Note: Parental income is measured in thousands of dollars. Other family background variables include: number of siblings, nuclear family, visible minority status and urban. T-statistics appear in parentheses. Highest grade completed is measured in December 2009.

Source: Youth in Transition Survey (YITS). 
Table 5. OLS regression results for females.

Dependent variable: Highest grade completed

\begin{tabular}{|c|c|c|c|c|c|c|}
\hline Independent variable & (1) & (2) & (3) & (4) & (5) & (6) \\
\hline Parental income & $0.008(11.1)$ & $0.006(8.2)$ & $0.005(7.6)$ & $0.004(5.6)$ & $0.004(6.1)$ & $0.004(6.4)$ \\
\hline \multicolumn{7}{|l|}{ Father's education: } \\
\hline High school & & $0.68(5.5)$ & $0.46(3.6)$ & $0.31(2.6)$ & $0.27(2.3)$ & $0.33(2.9)$ \\
\hline Above high school & & $1.68(15.4)$ & $1.29(11.0)$ & $0.97(8.7)$ & $0.83(7.5)$ & $0.88(8.1)$ \\
\hline \multicolumn{7}{|l|}{ Mother's education: } \\
\hline High school & & & $0.75(5.6)$ & $0.50(4.0)$ & $0.54(4.4)$ & $0.51(4.2)$ \\
\hline Above high school & & & $1.12(8.4)$ & $0.73(5.8)$ & $0.74(6.0)$ & $0.66(5.5)$ \\
\hline PISA reading score & & & & $0.01(22.5)$ & $0.01(22.5)$ & $0.01(22.5)$ \\
\hline $\begin{array}{l}\text { Controls for other } \\
\text { family background } \\
\text { variables }\end{array}$ & No & No & No & No & Yes & Yes \\
\hline $\begin{array}{l}\text { Controls for province of } \\
\text { residence }\end{array}$ & No & No & No & No & No & Yes \\
\hline
\end{tabular}

Note: Parental income is measured in thousands of dollars. Other family background variables include: number of siblings, nuclear family, visible minority status and urban. T-statistics appear in parentheses. Highest grade completed is measured in December 2009.

Source: Youth in Transition Survey (YITS). 
Table 6. Internal validation of the structural model - Comparing predicted and observed grade distributions.

\begin{tabular}{cccccc} 
& \multicolumn{2}{c}{ Males } & & \multicolumn{2}{c}{ Females } \\
\cline { 2 - 3 } \cline { 5 - 6 } Highest grade completed & Model & Data & & Model & Data \\
\hline 9 & 0.0 & 0.5 & & 0.0 & 0.0 \\
10 & 1.8 & 1.5 & & 0.9 & 1.2 \\
11 & 6.8 & 7.1 & & 5.2 & 4.8 \\
12 & 19.4 & 18.5 & & 11.6 & 12.5 \\
13 & 12.5 & 13.8 & & 11.6 & 11.7 \\
14 & 10.7 & 11.7 & & 9.3 & 10.7 \\
15 & 10.2 & 10.4 & & 9.5 & 10.1 \\
16 & 11.6 & 12.4 & & 17.2 & 17.6 \\
17 & 11.6 & 11.7 & & 14.8 & 14.6 \\
18 & 6.4 & 6.9 & & 9.0 & 10.1 \\
19 & 4.5 & 3.4 & & 6.3 & 4.6 \\
20 & 3.1 & 2.2 & & 3.3 & 2.2 \\
21 & 1.3 & 0.0 & & 1.5 & 0.0 \\
\hline
\end{tabular}

Source: Youth in Transition Survey (YITS). 
Table 7. Adjusted R-square values from regressing predicted schooling on observable characteristics.

\begin{tabular}{llc} 
Controls for: & Males & Females \\
\hline (1) Parental income & 0.020 & 0.028 \\
(2) Father's education + (1) & 0.078 & 0.084 \\
(3) Mother's education + (2) & 0.092 & 0.121 \\
(4) PISA reading score + (3) & 0.192 & 0.191 \\
(5) Controls for family background variables + (4) & 0.199 & 0.197 \\
(6) Controls for provinces + (5) & 0.224 & 0.240 \\
\hline
\end{tabular}

Note: Family background variables include: number of siblings and nuclear family. Control variables were step-wise added to illustrate the impact of their inclusion on the adjusted R-square values.

Source: Youth in Transition Survey (YITS). 
Table 8. Simulating effects on schooling from increases in parental income.

\begin{tabular}{lccccc} 
& & \multicolumn{2}{c}{ Males } & Increase parental \\
& Control & $\begin{array}{c}\text { Increase parental } \\
\text { income with 25\% }\end{array}$ & Change (in \%) & income with one std.dev. & Change (in \%) \\
\hline Highest grade completed & 14.7 & 14.7 & 0.1 & 0.7 \\
Less than Grade 12 & 0.088 & 0.087 & -1.3 & 0.084 & -5.2 \\
Grade 12 & 0.195 & 0.192 & -1.6 & 0.185 \\
More than Grade 12 & 0.717 & 0.720 & 0.5 & 0.732 & -5.2 \\
\hline
\end{tabular}

\begin{tabular}{lccccc} 
& \multicolumn{2}{c}{$\begin{array}{c}\text { Females } \\
\text { Control }\end{array}$} & $\begin{array}{l}\text { Increase parental } \\
\text { income with 25\% }\end{array}$ & $\begin{array}{c}\text { Change (in \%) } \\
\text { Increase parental } \\
\text { income with one std.dev. }\end{array}$ Change (in \%) \\
\hline Highest grade completed & 15.3 & 15.3 & 0.2 & 15.5 & 1.7 \\
Less than Grade 12 & 0.067 & 0.065 & -3.3 & 0.058 & -13.4 \\
Grade 12 & 0.118 & 0.112 & -5.2 & 0.101 & -14.6 \\
More than Grade 12 & 0.815 & 0.823 & 1.0 & 0.841 & 3.2 \\
\hline
\end{tabular}

Note: The standard deviation equals $\$ 5,130$ for males and $\$ 5,330$ for females.

Source: Youth in Transition Survey (YITS). 
Table 9. Simulating effects on schooling from a $\$ 2,500$ tuition fee increase.

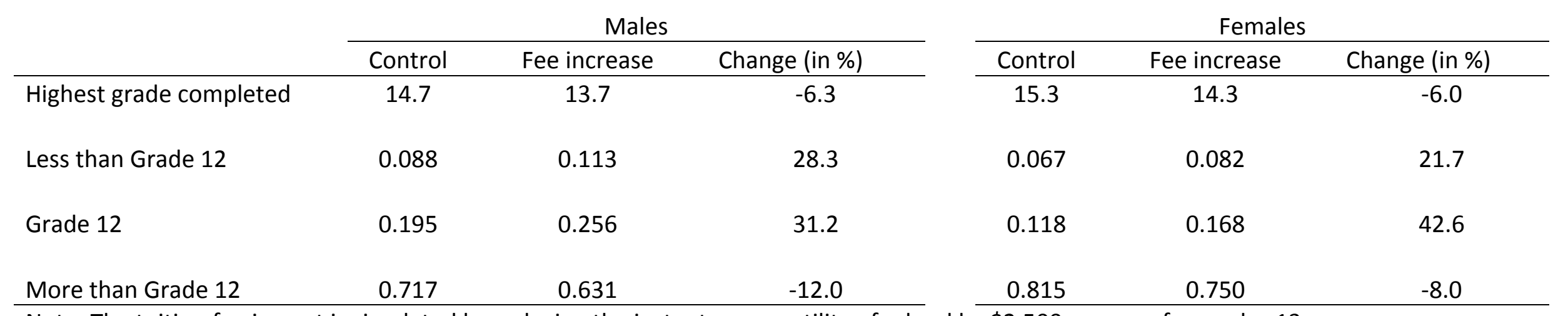

Note: The tuition fee impact is simulated by reducing the instantaneous utility of school by $\$ 2,500$ per year for grades 13 and above.

Source: Youth in Transition Survey (YITS). 
Table 10. Simulating effects on schooling from a $\$ 2,500$ subsidy for poor students.

\begin{tabular}{|c|c|c|c|c|c|c|}
\hline & \multicolumn{3}{|c|}{ Males } & \multicolumn{3}{|c|}{ Females } \\
\hline & Control & Subsidy & Change (in \%) & Control & Subsidy & Change (in \%) \\
\hline Highest grade completed & 14.1 & 14.9 & 5.5 & 14.6 & 15.4 & 5.8 \\
\hline Less than Grade 12 & 0.125 & 0.123 & -1.9 & 0.097 & 0.076 & -22.0 \\
\hline Grade 12 & 0.242 & 0.187 & -22.6 & 0.148 & 0.102 & -31.2 \\
\hline More than Grade 12 & 0.633 & 0.690 & 9.0 & 0.755 & 0.822 & 9.0 \\
\hline
\end{tabular}

Note: The tuition fee impact is simulated by reducing the instantaneous utility of school by $\$ 2,500$ per year for grades 13 and above.

Source: Youth in Transition Survey (YITS). 
Table 11. Simulating effects on schooling from an increase in PISA reading scores.

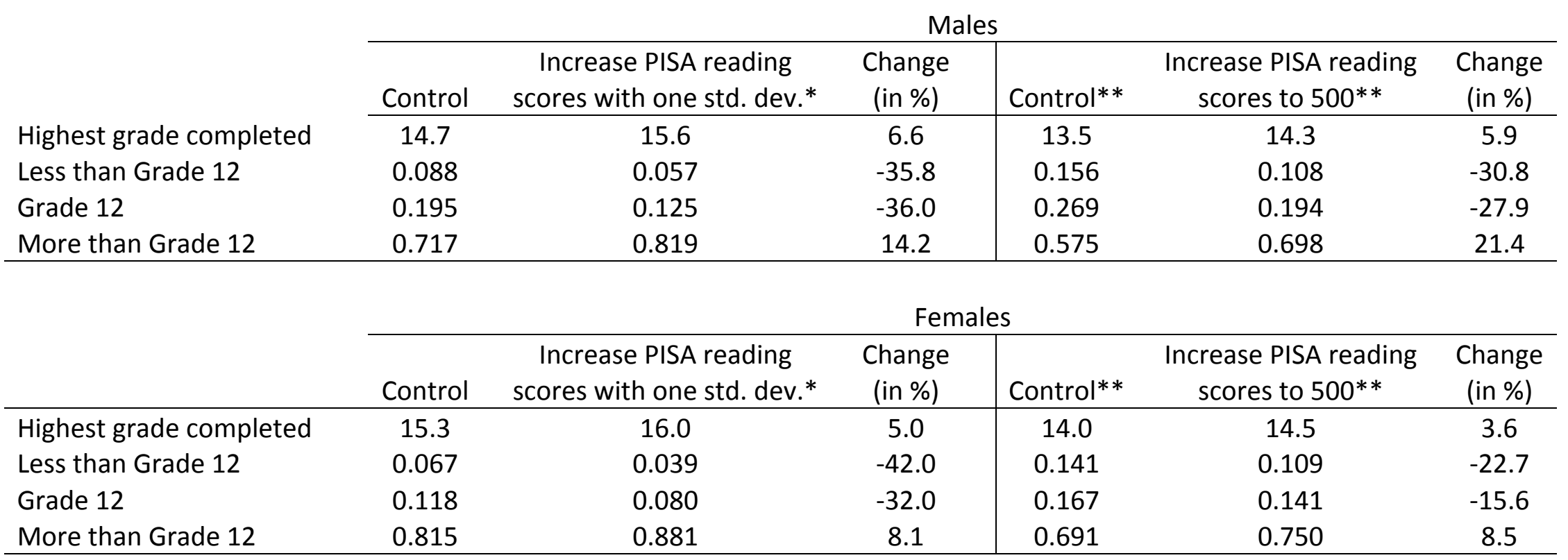

Note: * The standard deviation equals 91 for males and 84 for females.

** refers to a sub-sample consisting of students whose PISA scores were less than 500 .

Source: Youth in Transition Survey (YITS). 
Table 12. Simulating effects on schooling from increasing father's education.

\begin{tabular}{|c|c|c|c|c|c|c|}
\hline & \multicolumn{3}{|c|}{ Males } & \multicolumn{3}{|c|}{ Females } \\
\hline & Control & $\begin{array}{c}\text { Increase in Father's } \\
\text { Education }\end{array}$ & $\begin{array}{l}\text { Change } \\
\text { (in \%) }\end{array}$ & Control & $\begin{array}{c}\text { Increase in Father's } \\
\text { Education }\end{array}$ & $\begin{array}{c}\text { Change } \\
\text { (in \%) }\end{array}$ \\
\hline Highest grade completed & 14.7 & 14.9 & 1.8 & 15.3 & 15.5 & 1.3 \\
\hline Less than Grade 12 & 0.088 & 0.075 & -14.6 & 0.067 & 0.054 & -19.7 \\
\hline Grade 12 & 0.195 & 0.173 & -11.2 & 0.118 & 0.105 & -10.7 \\
\hline More than Grade 12 & 0.717 & 0.751 & 4.8 & 0.815 & 0.840 & 3.2 \\
\hline
\end{tabular}

Note: The increase sets father's education to PSE for everyone.

Source: Youth in Transition Survey (YITS). 
Table 13. Simulating effects on schooling from increasing the return to education.

\begin{tabular}{|c|c|c|c|c|c|c|}
\hline & \multicolumn{3}{|c|}{ Males } & \multicolumn{3}{|c|}{ Females } \\
\hline & & Wage & & & Wage & \\
\hline & Control & increase & Change (in \%) & Control & increase & Change (in \%) \\
\hline Highest grade completed & 14.6 & 14.7 & 0.3 & 15.3 & 15.4 & 0.9 \\
\hline Less than Grade 12 & 0.086 & 0.077 & -12.7 & 0.061 & 0.049 & -27.1 \\
\hline Grade 12 & 0.194 & 0.184 & -5.7 & 0.116 & 0.105 & -11.1 \\
\hline More than Grade 12 & 0.719 & 0.739 & 3.1 & 0.824 & 0.846 & 3.8 \\
\hline
\end{tabular}

Note: The return to education was increased by 25 .

Source: Youth in Transition Survey (YITS). 